\title{
The influence of connectivity in forest patches, and riparian vegetation width on stream macroinvertebrate fauna
}

\author{
Valle, IC..$^{a, b, c *}$, Buss, DF. ${ }^{b}$ and Baptista, DF. ${ }^{b}$ \\ aPrograma de Pós-graduação em Ciências Ambientais e Florestais, Departamento de Ciências Ambientais, \\ Universidade Federal Rural do Rio de Janeiro - UFRRJ, BR 465, Km 7, CEP 23890-000, Seropédica, RJ, Brazil

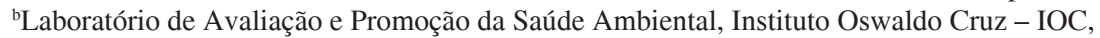 \\ Fundação Oswaldo Cruz - Fiocruz, Av. Brasil, 4365, Manguinhos, CEP 21045-900, Rio de Janeiro, RJ, Brazil \\ 'Programa de Pós-graduação em Ecologia e Conservação da Biodiversidade, Departamento de Ciências Biológicas, \\ Universidade Estadual de Santa Cruz - UESC, Rod. Ilhéus-Itabuna, Km 16, CEP 45662-900, Ilhéus, BA, Brazil \\ *e-mail: ivana_geouff@yahoo.com.br
}

Received February 14, 2012 - Accepted July 25, 2012 - Distributed May 31, 2013

(With 3 figures)

\begin{abstract}
We assessed two dimensions of stream connectivity: longitudinal (between forest patches along the stream) and lateral (riparian vegetation), using macroinvertebrate assemblages as bioindicators. Sites representing different land-uses were sampled in a lowland basin that holds a mosaic of protected areas. Land-use analysis, forest successional stages and riparian zone widths were calculated by the GIS analysis. Macroinvertebrate fauna was strongly affected by land-use. We observed a continuous decrease in the number of sensitive species, \%Shredders and IBE-IOC biotic index from the upstream protected area to highly deforested sites, increasing again where the stream crosses a Biological Reserve. When analysing buffer strips, we found aquatic fauna responding to land-use alterations beyond the $30 \mathrm{~m}$ riparian corridor (60 m and $100 \mathrm{~m}$ wide). We discussed the longitudinal connectivity between forest patches and the riparian vegetation buffer strips necessary to hold high macroinvertebrate diversity. We recommend actions for the increase/ maintenance of biodiversity in this and other lowland basins.
\end{abstract}

Keywords: bioassessment, biomonitoring, aquatic insects, riparian zone, conservation.

\section{Influência da conectividade dos fragmentos florestais e da largura da vegetação ripária sobre a fauna de macroinvertebrados em um ecossistema lótico}

\section{Resumo}

Neste trabalho, foram avaliadas duas dimensões de conectividade em um ecossistema lótico: longitudinal (entre fragmentos florestais ao longo do córrego) e lateral (mata ripária), utilizando-se assembléias de macroinvertebrados como indicadores. Pontos que representam diferentes tipos de usos da terra foram amostrados em uma bacia de planície litorânea, que abriga um mosaico de áreas protegidas. As análises de uso da terra, os estágios de sucessão florestal e as diferentes larguras da zona ripária foram calculados utilizando-se um SIG. A fauna de macroinvertebrados foi fortemente afetada pelo uso da terra. Partindo-se da área protegida à montante, observou-se um decréscimo contínuo do número de espécies sensíveis, da porcentagem de fragmentadores e do índice biótico IBE-IOC até o trecho fortemente desflorestado, no médio curso do rio; os valores aumentam novamente, quando o rio atravessa uma Reserva Biológica. Ao analisar a largura da vegetação ripária, constatou-se que a fauna aquática responde às alterações além do corredor ripário com $30 \mathrm{~m}$ de largura (60 m e $100 \mathrm{~m}$ de largura). Discutiu-se sobre a conectividade longitudinal entre fragmentos florestais e sobre a largura necessária da vegetação ripária para manter a alta diversidade de macroinvertebrados. Dessa forma, foram feitas recomendações visando a favorecer o aumento/a manutenção da biodiversidade, tanto na bacia analisada como em outras bacias localizadas em planícies litorâneas.

Palavras-chave: bioavaliação, biomonitoramento, insetos aquáticos, zona ripária, conservação.

\section{Introduction}

Stream systems are organised in nested spatial hierarchies - drainage basin, river segment, stream reach, microhabitats - and change over time (Frissell et al., 1986). Streams are connected to their basins through the lateral and longitudinal transport of materials derived from terrestrial habitats (Allan, 2004; França et al., 2009). The relationship between land-water is intermediated by the riparian habitat, which may or may not act as barriers to control runoff, sediments, nutrients and contaminants (Peterjohn and Correll, 1984; Johnson et al., 1997). 
In Brazil, the conversion of forests to pastures, agricultural land and/or urban areas is one of the main causes of impairment on water bodies. Protected areas are often created as a conservation strategy to halt the deforestation and start the recovery process in ecologically relevant areas. The limits of these Conservation Units are often defined following the patterns of terrestrial vegetation (Pereira and Scardua, 2008; Metzger, 2010), while the protection of aquatic assemblages are almost never considered (Maltchik et al., 2012). Riparian zones act as corridors for biodiversity (both aquatic and terrestrial) and Brazilian legislation treats them as "Permanent Protection Areas" (Áreas de Proteção Permanente).

Even though there are clear evidences on the importance of riparian zones in determining stream water quality and aquatic biodiversity (Johnson et al., 1997), it is not an easy task to determine effective models which predict the effects of riparian removal (or restoration) on aquatic ecosystems. Benefits of riparian vegetation include (according to Hansen et al., 2010, in no particular order): i) improvements of water quality, including the capture and/or uptake of non-point source pollutants - i.e. nutrients, sediments and contaminant inputs to waterways (Lowrance et al., 1997); ii) reduction of stream bank erosion and sediment inputs; iii) increase in shading and moderate water temperature (Welty et al., 2002); iv) provision of woody debris, leaf litter and other resource inputs to streams; v) increase of in-stream biodiversity; vi) improvements of the structure and composition of riparian vegetation communities, and increased terrestrial biodiversity; vii) increase in the lateral and longitudinal connectivity of biota and other materials. Connectivity from a landscape perspective can be defined as the flow of energy, matter and organisms between landscape components (Ward et al., 2002). In stream ecology, a four-dimensional model has proved useful, where flow along the stream (longitudinal), between the stream and riparian and upland areas (lateral), and between the channel and the hyporheic zone (vertical) is comprised of three spatial dimensions, and a fourth variation over time (Ward, 1989).

In this paper we studied a lowland basin in the state of Rio de Janeiro - which holds a mosaic of protected areas and environmental conditions - so we could assess the connectivity between forest patches, the influence of protected areas and the riparian width on the stream ecological condition, using the macroinvertebrate fauna as bioindicators.

Macroinvertebrates have been used worldwide to characterise watershed and water-quality conditions because they have a broad distribution, high diversity and because its assemblage composition, structure and functioning attributes react predictably to environmental alterations in multiple spatial scales and over time (Rosenberg and Resh, 1993; Vannote et al., 1980; Barbour et al., 1996). In recent years, researchers showed this assemblage to be useful for monitoring and assessment also in Brazil (e.g. Buss et al., 2003, 2004; Baptista et al., 2007; Moreno et al., 2009; Couceiro et al., 2012). Therefore, understanding how this assemblage behaves in natural and stressed ecosystems will help in ecological modelling, and thus, increase bioassessment abilities.

\section{Material and Methods}

We studied the Aldeia Velha River basin (total area of 14.400 hectares), located in the municipalities of Silva Jardim and Casimiro de Abreu, in Rio de Janeiro State (see Figure 1). This basin is part of the São João River system, which supplies water to many municipalities in one of the most developed and touristic regions of the state (Região dos Lagos). This basin is also particularly important because it holds the Biological Reserve (REBIO) Poço das Antas, which protects the last remnants of the natural habitat of the Golden Lion Tamarin (Leontopithecus rosalia). The REBIO was the first reserve created in Brazil, in 1974, with an area of 5.000 hectares. Other protected areas highlight the importance of this basin as a hotspot for biodiversity in the state - area of environmental protection (APA da Bacia do Rio São João/Mico-Leão-Dourado, created in 2002) and two Privates Reserves of Natural Heritage (RPPN Fazenda Bom Retiro, created in 1993, and Fazenda Shangrilá, created in 2006). The rationale of choosing this river basin for our study was to sample a reference basin in the lowlands of Rio de Janeiro State.

Land-use analysis, forest successional stages and riparian zone width were carried from manual interpretations of high resolution imagery from IKONOS satellite (2006) with $1 \mathrm{~m}$ of spatial resolution, using the functions of a geographical information system (ArcGis 9.2, ESRI, USA). To assess the influence of land-use on macroinvertebrate assemblages we analysed three levels: 30,50 and $100 \mathrm{~m}$ riparian width at each margin. The Brazilian legislation requires that streams with $<10 \mathrm{~m}$ wide the riparian forest should have a minimum width of $30 \mathrm{~m}$ on each margin.

Eight sites were sampled in 2009 during the dry season (winter), to represent different land-uses, ranging from protected areas to deforested sites (see Table 1). At each site, water samples were taken for physical and chemical analysis. Also, 20 macroinvertebrate samples were taken with a kick-sampler $(30 \times 30 \mathrm{~cm}$ squared-frame, $0.5 \mathrm{~mm}$ mesh size); as tested and recommended by Buss and Borges (2008), following a multi-habitat method proportional to the substrate availability in the site (Barbour et al., 1996; Hering et al., 2004). All samples were then combined into a single composite sample and preserved with $80 \%$ ethanol. In the laboratory, we adopted the subsampling procedure (as tested by Oliveira et al., 2010), which consisted in homogenising the sample on a gridded tray and taking randomly 6 of the 24 quadrats. These six subsamples were fully examined and macroinvertebrates were removed, counted and identified at the lower taxonomic level possible, which was genus-level for all groups but Diptera, Hemiptera and Lepidoptera, which were identified to familylevel. We then calculated Taxa Richness, EPT Richness (Ephemeroptera + Plecoptera + Trichoptera), percent of shredders (benthic organisms that feed predominantly 


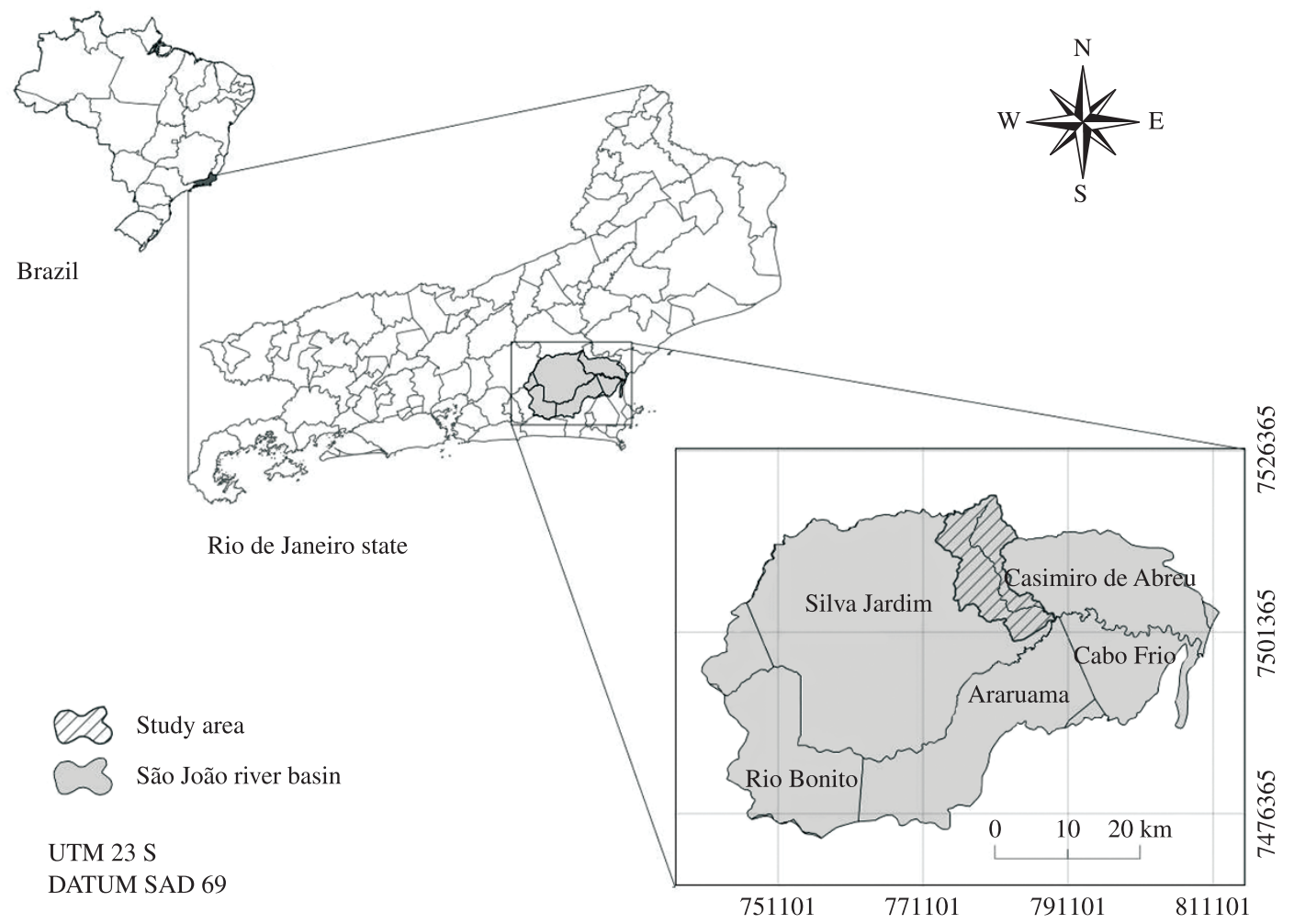

Figure 1. Location of São João river basin and the study area, the Aldeia Velha basin, RJ.

on fallen leaves) and the Indice Biotico Esteso (IBEIOC, Mugnai et al., 2008) for each site. We explored the correlations between these metrics and the percent of intermediate + advanced successional stage forests at three spatial scales (30,50 and $100 \mathrm{~m}$ wide riparian zones at each margin) using STATISTICA (Statsoft, 2004). Rare species (one individual) were excluded to avoid accidental capture that could add ecological noise to the analyses.

\section{Results}

GIS land-use analysis revealed a mosaic of aquatic ecosystems (wetlands and streams) and vegetation types (see Figure 2). Considering the whole Aldeia Velha river basin, the most common land-use was forest (53\%), but with a major proportion in the high-slope mountainous region (76\%) and in the early stages of development $(68 \%)$. Even inside the REBIO Poço das Antas, forest cover was $57 \%$ in early stages, dominated predominantly by shrubs and small/ young heliophilous flood-tolerant trees (e.g. Calophyllum brasiliense, Symphonia globulifera Clusiaceae, Tabebuia cassinoides Bignoniaceae; Carvalho et al., 2006). Pasture was also common in the basin $(23 \%)$ and dominant in the lowlands. In the studied area (lowland part of the basin), land-use was a mixture of pasture/early-stage forests $(69 \%)$ with some agriculture (15\%) and small peri-urban areas $(2 \%)$.

Macroinvertebrate fauna was strongly affected by land-use. We observed a continuous decrease in the number of species, EPT sensitive species and IBE-IOC biotic index from the upstream RPPN protected area (site 1) to the intermediately deforested reaches (sites 2 and 3 ) and the $100 \%$ pasture-dominated reach (site 4) (see Figure 3). Sensitive groups like Gripopteryx (Plecoptera, Gripopterygidae) and Trichodactylus dentatus (Decapoda, Trichodactylidae) were found exclusively in site 1 . Forested reaches on the border of the REBIO acted in the recovery of the fauna, increasing the total number of families and the sensitive groups EPT and IBE-IOC index (sites 5 and 6; see Figure 3). The reference area inside the REBIO (site 7) had more sensitive species (EPT richness and IBE-IOC number) than border sites (5 and 6). Sensitive groups like Kempnyia (Plecoptera, Perlidae) and Potimirim sp. (Decapoda, Atyidae) were found exclusively in site 7. Downstream from these sites, around $1 \mathrm{~km}$ from the influence of the REBIO, the richness numbers dropped (see Figure 3 ) and the assemblage was dominated by the tolerant dipteran family Chironomidae (87\% of the total abundance in site 8). Despite this clear environmental and biological gradient, the analysis of the water indicated no physical or chemical stress (values found at all sites were within ranges established by CONAMA 357/05 (Brasil, 2005) for Class 2 rivers: higher values $\mathrm{NH}_{3} 0.06 \mathrm{mg} / \mathrm{L}$ at site $2 ; 1 \mathrm{mg} / \mathrm{L} \mathrm{N}$-total at site 8 ; P-total $0.44 \mathrm{mg} / \mathrm{L}$ at site 6; Conductivity $26 \mu \mathrm{S} / \mathrm{cm}$ at site 6; TDS $20.3 \mathrm{ppm}$ at site 7; Fecal coliforms $613 \mathrm{mpn} / 100 \mathrm{~mL}$ at site 3; Dissolved oxygen lower value $7.6 \mathrm{mg} / \mathrm{L}$ at site 8 ). 
Valle, IC., Buss, DF. and Baptista, DF.

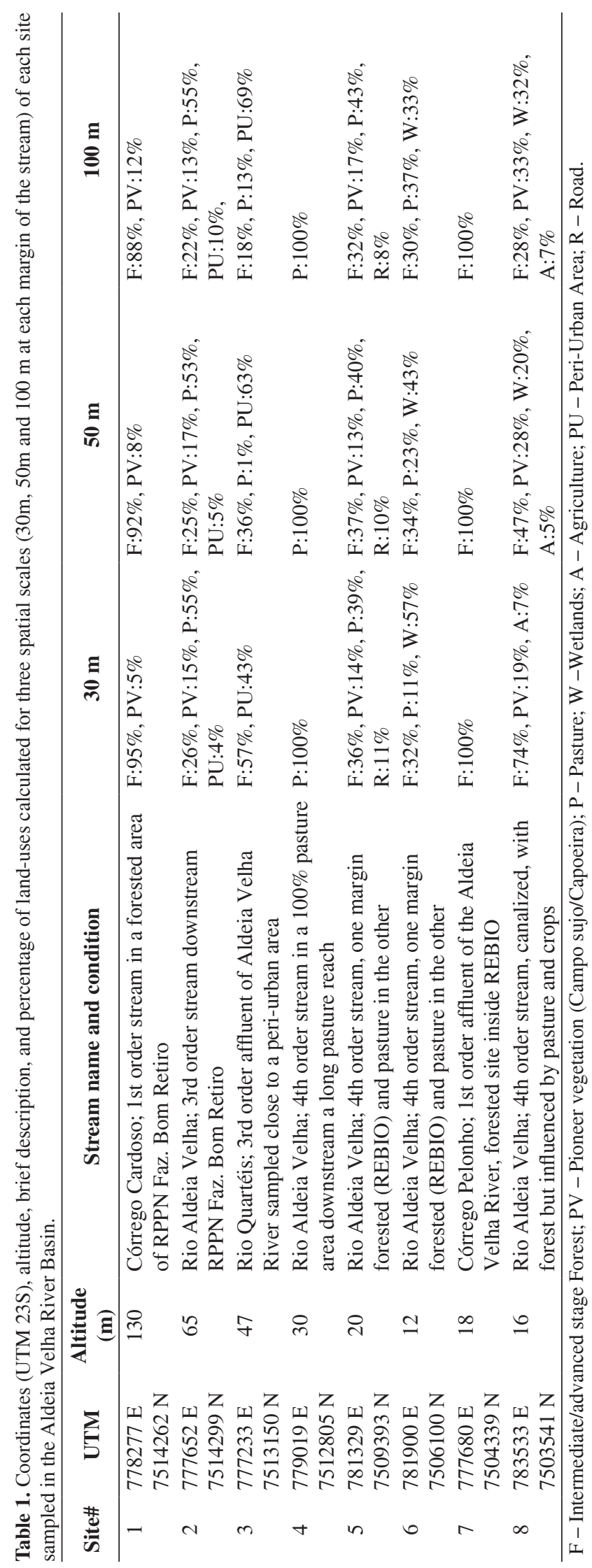




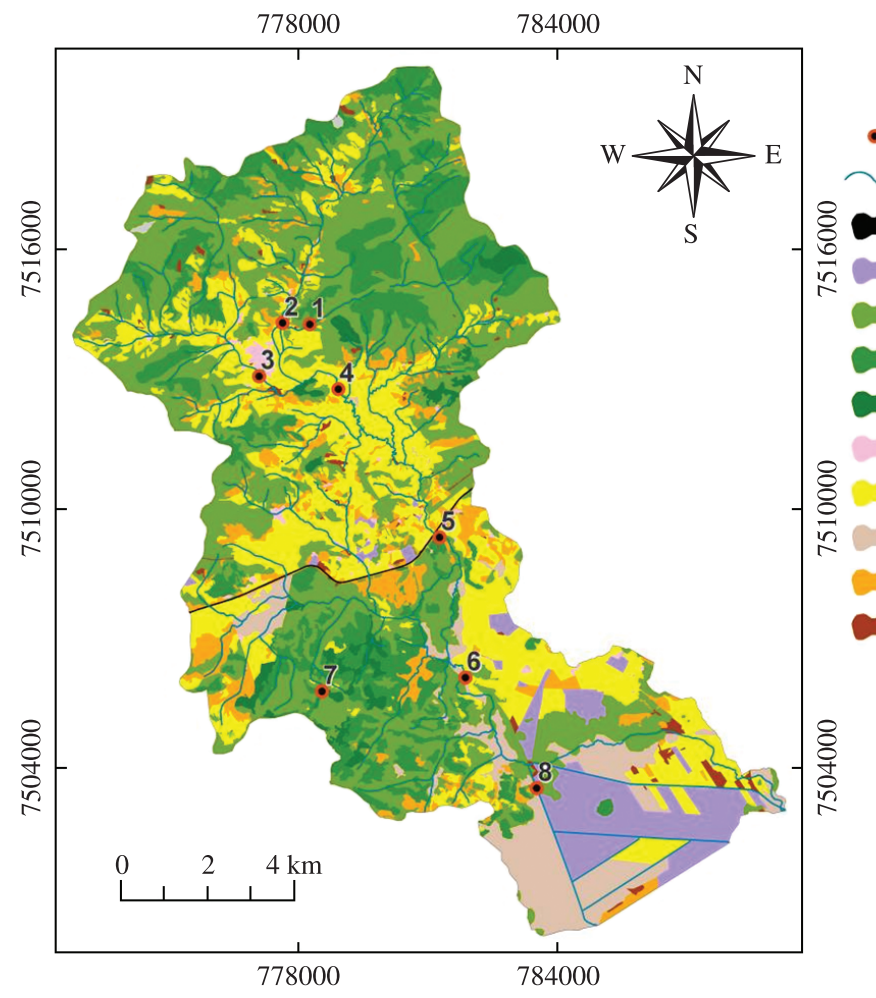

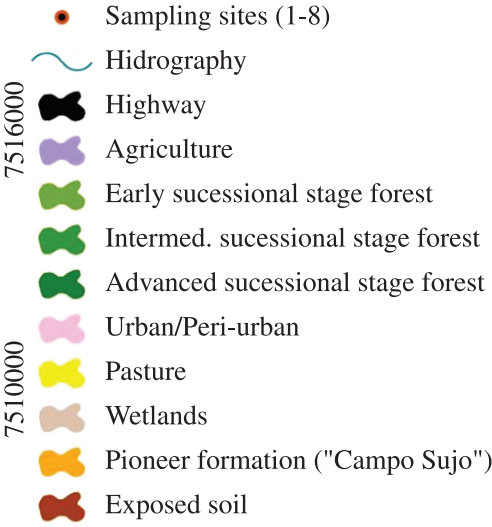

Figure 2. Sampling sites (1-8) and land-use types in Aldeia Velha basin, RJ.

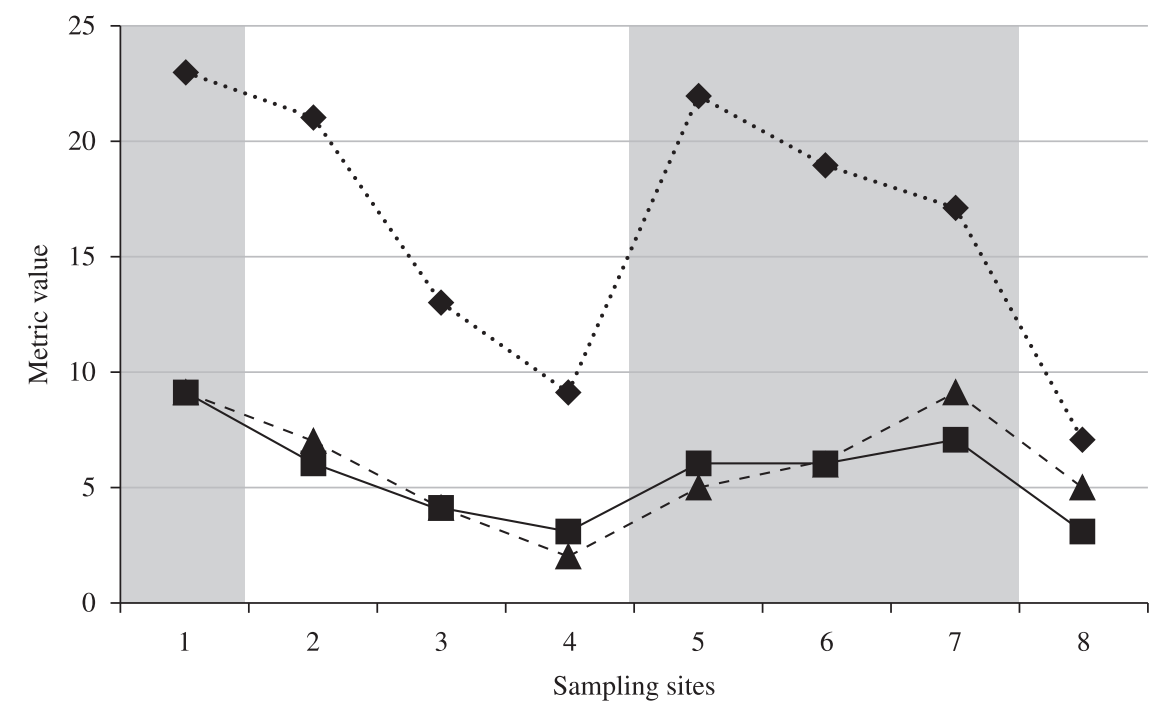

Figure 3. Metric values of taxa richness

, IBE-IOC index Aldeia Velha basin. Grey shades indicate forested areas.

When analysing buffer strips, our results indicate that the aquatic fauna was responding to land-use alterations beyond the $30 \mathrm{~m}$ riparian corridor - length established by the Brazilian legislation as the minimum area of riparian cover required to protect streams and rivers with a width of $<10 \mathrm{~m}$. All biological metrics had higher correlation coefficients with land-use in broader riparian widths (see Table 2). No biological metrics were correlated with the $30 \mathrm{~m}$ riparian scale. EPT richness, \%Shredders and IBEIOC index were correlated with $60 \mathrm{~m}$ and $100 \mathrm{~m}$ riparian 
Table 2. Pearson correlations between biological indicators (IBE-IOC, percent of Shredders, Ephemeroptera + Plecoptera + Trichoptera EPT Richness, Total Richness) and percent of intermediate+advanced successional stage forests at three spatial scales (30, 50 and $100 \mathrm{~m}$ wide riparian zones at each margin) in the Aldeia Velha river basin.

\begin{tabular}{lccc}
\hline & \multicolumn{3}{c}{$\begin{array}{c}\text { \% Forested area in riparian zone } \\
\text { width at each margin }\end{array}$} \\
\cline { 2 - 4 } & $\mathbf{3 0 ~ \mathbf { ~ m }}$ & $\mathbf{5 0} \mathbf{~ m}$ & $\mathbf{1 0 0} \mathbf{~ m}$ \\
\hline IBE-IOC & 0.51 & $0.71^{*}$ & $0.79^{*}$ \\
\%Shredders & 0.69 & $0.83^{* *}$ & $0.89^{* *}$ \\
EPT Richness & 0.69 & $0.86^{* *}$ & $0.89 * *$ \\
Total Richness & 0.14 & 0.36 & 0.45 \\
\hline
\end{tabular}

$* \mathrm{p}<0.05 ; * * \mathrm{p}<0.01$

widths. Like the others, the total number of taxa increased correlation coefficient with the riparian spatial scale, but uncorrelated with all three widths.

We found shredders occurring only in areas where both local and upstream reaches were intensely forested. This is an indication that these organisms are responding to the availability of leaves in the upstream area. A higher percentage of shredders occurred in site 7 ( $>4,0 \%$ of total; an area where the headwaters are protected by the REBIO and $100 \%$ forested upstream), but also in site 1 (1.7\% of total; an area where around $70 \%$ upstream were covered with forest) and a lower proportion in site $2(0.35 \%$ of total), probably influenced by drift from site 1 .

\section{Discussion}

Our analysis showed that although a larger part of the basin was forested (including a Biological Reserve) and physical-chemical parameters of the water indicated no sign of stress, the overall biological quality of the basin was moderate. Forested areas in this basin were not homogeneously distributed; on the contrary, it presented patches of vegetation intermediated by other land-uses, especially for pasture.

Connectivity plays a key role in freshwater biodiversity conservation (Hermoso et al., 2011), but it is not typically considered in scientific literature for dealing with the management and conservation of fragmented landscapes (Pringle, 2001). We assessed longitudinal connectivity by sampling sites along the river canal and verifying changes in macroinvertebrate assemblages. Connectivity of aquatic insect populations can occur by downstream passive or active drift and/or by upstream movements of the flying adults. Data from the literature indicates that leaves and other riparian debris are retained some $100 \mathrm{~m}$ below falling point into the stream (Mathooko et al., 2001; Canhoto and Graça, 1998) and/or relatively high retention/deposition rates within this range (Afonso and Henry, 2002; Selva et al., 2007). Although variable among taxa, macroinvertebrate drift rates range from 5-60m/day downstream (Waters, 1965; 1972; McLay, 1970; Hemsworth and Brooker, 1979). Information on the dispersal potential of neotropical adult aquatic insects is unavailable, but some studies on mark-recapture using stable isotopes have revealed that temperate species fly $1.6-1.9 \mathrm{~km}$ upstream from where they emerged (Hershey et al., 1993; Bilton et al., 2001). In short, both downstream and upstream potential for colonisation suggest a low connectivity between forested patches $-15 \mathrm{~km}$ with no riparian cover separate to the REBIO Poço das Antas from the upstream patch - explaining in part the low overall biodiversity found in this basin.

Our findings of shredder presence associated only to areas where both local and upstream reach was forested also corroborate to the importance of downstream gradient connectivity. Shredders need a certain amount of CPOM which takes some time to be ready to be consumed (Gessner et al., 1999). As a contribution to conservation biology, our results support the use of these taxa (Trichoptera - Phylloicus and Triplectides, Diptera - Tipulidae) as bioindicators of upstream forestation (i.e. their presence with high abundance indicate a certain amount of forested area upstream and, following the inverse rationale, their absence may be an indicative of deforestation).

The effectiveness of riparian zones in mitigating anthropogenic impacts largely depends on their width on both sides of the waterway (Castelle et al., 1994) and their longitudinal continuity from the headwaters to lowland reaches. It is not an easy task to determine the riparian width required to fulfill ecological, geomorphologic and hydrologic functions because the riparian zone is influenced by many aspects, such as slope, climate (rainfall), physiography, soil and vegetation type. Nonetheless, many studies have addressed this issue. A meta-analysis with 222 studies (Hansen et al., 2010), indicate that for increasing in-stream biodiversity the recommended riparian buffer width is $100 \mathrm{~m}$ for high land-use intensity, $70 \mathrm{~m}$ for moderate intensity and $40 \mathrm{~m}$ for low intensity. The Aldeia Velha basin could be classified as having low to moderate land-use intensity and we found that macroinvertebrate fauna was correlated to a land-use of $60 \mathrm{~m}$ and $100 \mathrm{~m}$, corroborating the meta-analysis of Hansen et al. (2010) and also the results of Metzger (2010) and Sponseller et al. (2011). Our finding is a direct contribution to the recent discussion on the Brazilian Forest Code, and indicates that to support aquatic biodiversity the riparian strip should be larger than $30 \mathrm{~m}$ in each margin.

As a recommendation to the recovery of this important area, which supports a high biodiversity, including the last remnants of the natural habitat of the Golden Lion Tamarin and other endangered species, we made suggestions based on our results:

- Recover riparian forest strips. Our spatial analysis indicated that less than $50 \%$ of the riparian strips are planted. Large parts of the basin have no riparian vegetation at all and many areas have less than $30 \mathrm{~m}$ buffer in each margin or have one margin protected by the REBIO, while the other is exposed, with no vegetation. Rehabilitation or protection on one side of the waterway and not the other compromise management efforts, because the benefits of one bank are nullified by disturbances originated from the other. We 
suggest these areas should be recovered to attend the Brazilian legislation.

- Riparian strips must be more than $60 \mathrm{~m}$ wide in each margin. We showed that macroinvertebrates are influenced by a riparian use of $>60 \mathrm{~m}$ and were uncorrelated with buffers of $30 \mathrm{~m}$. Studies around the world with other organisms have shown the same. Therefore, we indicate that to support aquatic biodiversity the riparian strip should be larger than $30 \mathrm{~m}$ and planted in both margins.

- Maintain and recover the REBIO Poço das Antas. The REBIO occupies about $20 \%$ of the whole basin, but less than $43 \%$ of its designated area is covered with forests at intermediate or advanced successional stages. Protected areas are slowly recovering the vegetation, and patches of forests at different successional stages are evident. However, even with areas dominated by vegetation in the early stages, we showed that the REBIO had a beneficial effect on the aquatic biodiversity, increasing the richness of macroinvertebrates assemblage when compared to upstream and downstream sites crossing pasture lands. Our results from $100 \%$ protected areas with fully grown vegetation indicate that these beneficial effects on the aquatic fauna will increase in time with the establishment of a more mature vegetation. Protected areas in Brazil are often created as a conservation strategy for endangered species (plants, animals etc.). Aquatic assemblages are almost never considered in such strategies. We suggest that stream headwaters are included in conservation plans to ensure the protection of these communities.

We believe that attending these three recommendations would increase the connectivity of macroinvertebrate populations between patches of vegetation that nowadays are too far apart and provide inadequate conditions for migration and colonisation. Maximizing the lateral and longitudinal extent of intact riparian zones, starting in the headwaters, provides the best protection for the waterway. As a result, we would expect the increase in aquatic biodiversity in the region.

Acknowledgements - We are grateful to the team of the AMLD (Golden Lion Tamarin Association) and REBIO (Biological Reserve) Poço das Antas for operational support, to Prefeitura Municipal de Silva Jardim for the Ikonos image and A. Sattamini, C. Vieira, L. Fernandes, R. Oliveira, P. Pereira, R. Mugnai, R. Fonseca, and V. Valin for field and lab help. Financial Support: governmental Brazilian agencies - CAPES and PROEP/CNPq $\mathrm{N}^{\circ}$ 400107/2011-2.

\section{References}

AFONSO, AAO. and HENRY, R., 2002. Retention of particulate organic matter in a tropical headstream. Hydrobiologia, vol. 482, p. 161-166. http://dx.doi.org/10.1023/A:1021220600302

ALLAN, JD., 2004. Landscapes and riverscapes: the influence of land use on stream ecosystems. Annual Review of Ecology Evolution and Systematics, vol. 35, p. 257-284. http://dx.doi. org/10.1146/annurev.ecolsys.35.120202.110122
BAPTISTA, DF., BUSS, DF., EGLER, M., GIOVANELLI, A., SILVEIRA, MP. and NESSIMIAN, JL., 2007. A multimetric index based on benthic macroinvertebrates for evaluation of Atlantic Forest streams at Rio de Janeiro State, Brazil. Hydrobiologia, vol. 575, p. 83-94. http://dx.doi.org/10.1007/s10750-006-0286-X

BARBOUR, MT., GERRITSEN, J., GRIFITH, GE., FRYDENBORG, R., CARRON, EC., WHITE, JS. and BASTIAN, ML., 1996. A framework for biological criteria for Florida streams using benthic macroinvertebrates. Journal of the North American Benthological Society, vol. 15, no. 2, p.185-211. http://dx.doi. org/10.2307/1467948

BILTON, DT., FREELAND, JR. and OKAMURA, B., 2001. Dispersal in freshwater invertebrates. Annual Review of Ecology, Evolution, and Systematics, vol. 32, p. 159-81. http://dx.doi. org/10.1146/annurev.ecolsys.32.081501.114016

Brasil. Ministério do Meio Ambiente - MMA. Conselho Nacional do Meio Ambiente - CONAMA, 2005. Resolução n 357, de 17 de março de 2005. Dispõe sobre a classificação dos corpos de água e diretrizes ambientais para o seu enquadramento, bem como estabelece as condições e padrões de lançamento de efluentes, e dá outras providências. Diário Oficial da República Federativa do Brasil, Brasília, 18 mar.

BUSS, DF., BAPTISTA, DF., NESSIMIAN, JL. and EGLER, M., 2004. Substrate specificity, environmental degradation and disturbance structuring macroinvertebrate assemblages in neotropical streams. Hydrobiologia, vol. 518, no. 1, p. 179-188. http://dx.doi.org/10.1023/B:HYDR.0000025067.66126.1c

BUSS, DF. and BORGES, EL., 2008. Application of Rapid Bioassessment Protocols (RBP) for benthic macroinvertebrates in Brazil: comparison between sampling techniques and mesh sizes. Neotropical Entomology, vol. 37, p. 288-295. PMid:18641899. http://dx.doi.org/10.1590/S1519-566X2008000300007

BUSS, DF., BAPTISTA, DF. and NESSIMIAN, JL., 2003. Bases conceituais para aplicação de biomonitoramento em programas de avaliação da qualidade de rios. Cadernos de Saúde Pública, vol. 19, p. 465-473. PMid:12764462. http://dx.doi.org/10.1590/ S0102-311X2003000200013

CANHOTO, C. and GRAÇA, MAS., 1998. Leaf retention: a comparative study between two stream categories and leaf types. Verhandlungen des Internationalen Verein Limnologie, vol. 26, p. 990-993.

CARVALHO, FA., NASCIMENTO, MT., BRAGA, JMA. and RODRIGUES, PJFP., 2006. Estrutura da comunidade arbórea da floresta atlântica de baixada periodicamente inundada na Reserva Biológica de Poço Das Antas, Rio De Janeiro, Brasil. Rodriguésia, vol. 57, no. 3, p. 503-518.

CASTELLE, AJ., JOHSON, AW. and CONOLLY, C., 1994. Wetland and stream buffer size requirements - a review. Journal of Environmental Quality, vol. 23, p. 878-882. http://dx.doi. org/10.2134/jeq1994.00472425002300050004x

COUCEIRO, SRM., HAMADA, N., FORSBERG, BR., PIMENTEL, TP. and LUZ, SLB., 2012. A macroinvertebrate multimetric index to evaluate the biological condition of streams in the Central Amazon region of Brazil. Ecological Indicators, vol. 18, p. 118125. http://dx.doi.org/10.1016/j.ecolind.2011.11.001

FRANÇA, JS. GREGÓRIO, RS., DE PAULA, JD., GONÇALVES JÚNIOR, JF., FERREIRA, FA. and CALLISTO, M., 2009. Composition and dynamics of allochthonous organic matter inputs and benthic stock in a Brazilian stream. Marine and Freshwater Research, vol. 60, p. 990-998. http://dx.doi.org/10.1071/MF08247 
FRISSELL, CA., LISS, WJ., WARREN CE. and HURLEY, MC., 1986. A hierarchical framework for stream habitat classification: viewing streams in a watershed context. Environmental Management, vol. 10, p. 199-214. http://dx.doi.org/10.1007/BF01867358

GESSNER, MO., CHAUVET, E. and DOBSON, M., 1999. A perspective on leaf litter breakdown in streams. Oikos, vol. 85, p. 377-384. http://dx.doi.org/10.2307/3546505

HANSEN, B., REICH, P., LAKE PS. and CAVAGNARO, T., 2010. Minimum width requirements for riparian zones to protect flowing waters and to conserve biodiversity: a review and recommendations with application to the State of Victoria. Report to the Office of Water, Victorian Department of Sustainability and Environment. Monash University. 150 p.

HEMSWORTH, RJ. and BROOKER, MP., 1979. The rate of downstream displacement of macroinvertebrates in the upper Wye, Wales. Holartic Ecology, vol. 2, p. 130-136.

HERING, D., MOOG, O., SANDIN, L. and VERDONSCHOT, PFM., 2004. Overview and application of the AQEM assessment system. Hydrobiologia, vol. 516, p. 1-20. http://dx.doi.org/10.1023/ B:HYDR.0000025255.70009.a5

HERMOSO, V., LINKE, S., PRENDA, J. and POSSINGHAM, HP., 2011. Addressing longitudinal connectivity in the systematic conservation planning of fresh waters. Freshwater Biology, vol. 56, p. 57-70. http://dx.doi.org/10.1111/j.1365-2427.2009.02390.x

HERSHEY, AE., PASTOR, J., PETERSON, BJ. and KLING, GW., 1993. Stable isotopes resolve the drift paradox for Baetis mayflies in an arctic river. Ecology, vol. 74, p. 2315-2325. http:// dx.doi.org/10.2307/1939584

JOHNSON, LB., RICHARDS, C., HOST, GE. and ARTHUR, JW., 1997. Landscape influences on water chemistry in Midwestern stream ecosystems. Freshwater Biology, vol. 37, p. 193-208. http:// dx.doi.org/10.1046/j.1365-2427.1997.d01-539.x

LOWRANCE, R., ALTIER, LS., NEWBOLD, JD., SCHANABEL, RR., GROFFMAN, PM., DENVER, JM., CORREL, DL., GILLIAN, JW., ROBINSON, JL., BRONSFIELD, RB., STAVER, KW., LUCAS, W. and TODD, AH., 1997. Water quality functions of riparian forest buffers in Chesapeake Bay watersheds. Environmental Management, vol. 21, p. 687-712. PMid:9236284. http://dx.doi. org/10.1007/s002679900060

MALTCHIK, L., DALZOCHIO, MS., STENERT, C. and ROLON, AS., 2012. Diversity and distribution of aquatic insects in Southern Brazil wetlands: implications for biodiversity conservation in a Neotropical region. Revista de Biologia Tropical, vol. 60, no. 1, p. 273-289. PMid:22458224.

MATHOOKO, JM., MORARA, GO. and LEICHTFRIED, M., 2001. Leaf litter transport and retention in a tropical Rift Valley stream: an experimental approach. Hydrobiologia, vol. 443, p. 9-18. http://dx.doi.org/10.1023/A:1017542617696

McLAY, CL., 1970. A theory concerning the distance travelled by animals entering the drift of a stream. Journal of the Fisheries Board of Canada, vol. 27, p. 359-370. http://dx.doi.org/10.1139/ f70-041

METZGER, JP., 2010. O Código Florestal tem Base Científica? Natureza \& Conservação, vol. 8. no. 1, p. 92-99. http://dx.doi. org/10.4322/natcon.00801017

MORENO, P., FRANÇA, JS., FERREIRA, WR., PAZ, AD., MONTEIRO, IM. and CALLISTO, M., 2009. Use of the BEAST model for biomonitoring water quality in a neotropical basin.
Hydrobiologia, vol. 630, p. 231-242. http://dx.doi.org/10.1007/ s10750-009-9796-7

MUGNAI, R., OLIVEIRA, RBS., CARVALHO, AL. and BAPTISTA, DF., 2008. Adaptation of the Indice Biotico Esteso (IBE) for water quality assessment in rivers of Serra do Mar, Rio de Janeiro State, Brazil. Tropical Zoology, vol. 21, p. 57-74.

OLIVEIRA, RBS., MUGNAI, R., CASTRO, CM. and BAPTISTA, DF., 2010. Determining subsampling effort for the development of a rapid bioassessment protocol using benthic macroinvertebrates in streams of Southeastern Brazil. Environmental Monitoring Assessment, vol. 175, p. 75-85. PMid:20495956.

PEREIRA, PF. and SCARDUA, FP., 2008. Espaços territoriais especialmente protegidos: conceito e implicações jurídicas. Ambiente \& Sociedade, vol. 11, no. 1, p. 81-97.

PETERJOHN, WT. and CORRELL, DL., 1984. Nutrient dynamics in an agricultural watershed: observation on the role of a riparian forest. Ecology, vol. 65, p. 1466-1475. http://dx.doi.org/10.2307/1939127

PRINGLE, CM., 2001. Hydrologic connectivity and the management of biological reserves: a global perspective. Ecological Applications, vol. 11, no. 4, p. 981-998. http://dx.doi.org/10.1890/10510761(2001)011[0981:HCATMO]2.0.CO;2

ROSENBERG, DM. and RESH, VH., 1993. Introduction to freshwater biomonitoring and benthic Macroinvertebrates. In ROSENBERG, DM. and RESH, VH. (Eds.). Freshwater biomonitoring and benthic macroinvertebrates. New York: Chapman and Hall. p. 1-9.

SELVA, EC., COUTO, EG. JOHNSON, MS. and LEHMANN, J., 2007. Litterfall production and fluvial export in headwater catchments of the southern Amazon. Journal of Tropical Ecology, vol. 23, p. 329-335. http://dx.doi.org/10.1017/S0266467406003956

SPONSELLER, RA., BENFIELD, EF. and VALETT, HM., 2001. Relationships between land use, spatial scale and stream macroinvertebrate communities. Freshwater Biology, vol. 46, p. 1409-1424. http://dx.doi.org/10.1046/j.1365-2427.2001.00758.x

Statsoft, 2004. STATISTICA (data analysis software system). version 7. Tulsa: Statsoft Inc.

VANNOTE, RL., MINSHALL, GW., CUMMINS, KW., SEDELL, JR. and CUSHING, CE., 1980. The river continuum concept. Canadian Journal of Fisheries and Aquatic Sciences, vol. 37, p.130-137. http://dx.doi.org/10.1139/f80-017

WARD, JV., ARSCOTT, DB. and CLARET, C., 2002. Riverine landscape diversity. Freshwater Biology, vol. 47, p. 517-539. http://dx.doi.org/10.1046/j.1365-2427.2002.00893.x

WARD, JV., 1989. The four-dimensional nature of lotic ecosystems. Journal of the North American Benthological Society, vol. 8, p. 2-8. http://dx.doi.org/10.2307/1467397

WATERS, TF., 1965. Interpretation of invertebrate drift in streams. Ecology, vol. 46, p. 327-333. http://dx.doi.org/10.2307/1936336

-, 1972. The drift of stream insects. Animal Review of Entomology, vol. 17, p. 253-267. http://dx.doi.org/10.1146/annurev. en.17.010172.001345

WELTY, JJ., BEECHIE, T., SULLIVAN, K., HYINK, DM., BILBY, RE., ANDRUS, C. and PESS, G., 2002. Riparian aquatic interaction simulator (RAIS): a model of riparian forest dynamics for the generation of large woody debris and shade. Forest Ecology and Management, vol. 162, p. 299-318. http:// dx.doi.org/10.1016/S0378-1127(01)00524-2 